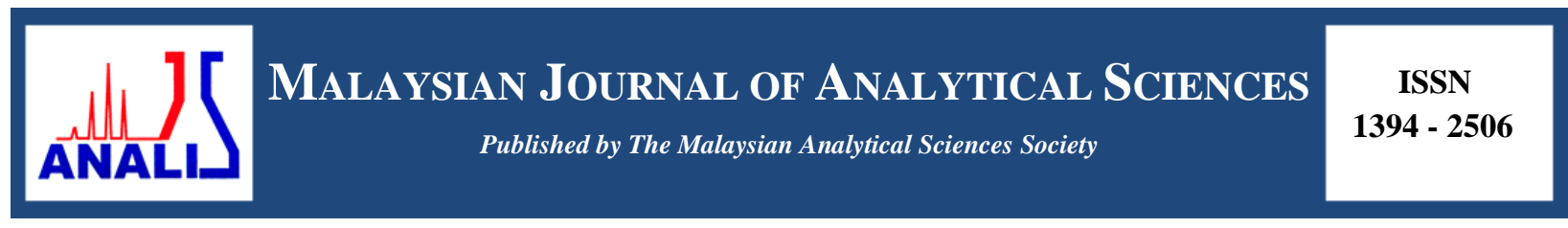

\title{
SYNTHESIS AND CHARACTERISATION OF NANOHYBRID ANTI- HYPERTENSIVE DRUG, CAPTOPRIL INTERCALATED INTO ZINC-ALUMINIUM LAYERED DOUBLE HYDROXIDE
}

\author{
(Sintesis dan Pencirian Nanohibrid Ubat Anti-Hipertensi, Captopril Tersisip ke dalam \\ Zink-Aluminium Hidroksida Berlapis Ganda) \\ Zaemah Jubri $^{1}$, Siti Halimah Sarijo ${ }^{2}$, Monica Limau Anak Jadam ${ }^{1}$ \\ ${ }^{1}$ Centre for Advanced Materials, \\ Universiti Tenaga Nasional, 43000 Kajang, Selangor, Malaysia \\ ${ }^{2}$ Faculty of Applied Sciences, \\ Universiti Teknologi MARA, 40450 Shah Alam, Selangor, Malaysia \\ *Corresponding author: zaemah@uniten.edu.my
}

Received: 19 August 2018; Accepted: 10 March 2019

\begin{abstract}
Captopril (CPL), an anti-hypertensive drug was intercalated into the interlayer spaces of zinc-aluminium layered double hydroxide (ZLDH) for the formation of zinc-aluminium-captopril (ZCPL) hybrid nanocomposite material by self-assembly method. The concentration of CPL used was $0.08 \mathrm{M}$ with pH 7.5 in a constant 3:1 molar ratio of zinc ( $\mathrm{Zn}$ ) to aluminium (Al) in the mother liquor. As a result of the successful intercalation of CPL, powder X-ray diffraction pattern (PXRD) shows the basal spacing increased from $8.90 \AA$ in ZLDH to $9.69 \AA$ in the ZCPL nanohybrid material. Fourier transform infrared (FTIR) spectroscopy study shows the intercalated compound of ZCPL resembled the spectra of ZLDH and CPL, thus indicating the presence of both functional groups in ZCPL spectra. CHNS analysis shows the ZCPL nanohybrid material contains $30.63 \%$ (w/w) of CPL which was calculated based on the percentage of carbon in the sample. It was also found that the BET surface area increased from $1.7 \mathrm{~m}^{2} / \mathrm{g}$ in ZLDH to $10.9 \mathrm{~m}^{2} / \mathrm{g}$ in ZCPL. The pore texture of the resulting material was also changed as the result of the intercalation and the expansion of the basal spacing during the formation of the layered intercalated ZCPL nanohybrid material.
\end{abstract}

Keywords: captopril, anti-hypertensive drug, intercalation, layered double hydroxide, nanocomposite

\begin{abstract}
Abstrak
Captopril (CPL) iaitu ubat anti-hipertensi telah berjaya disisipkan ke dalam ruang antara lapis hidroksida berlapis ganda bagi pembentukan bahan hibrid ZCPL nanokomposit melalui kaedah pembentukan sendiri. Kepekatan CPL yang digunakan adalah $0.08 \mathrm{M}$ dan $\mathrm{pH} 7.5$ dengan nisbah kepekatan tetap $\mathrm{Zn}$ : Al adalah $3: 1$ dalam larutan akueous. Penyisipan anion captopril dapat ditentukan dari pengembangan jarak basal PXRD daripada $8.90 \AA$ bagi zink-aluminium hidroksida berlapis ganda (ZLDH) kepada 9.69 ̊ bagi bahan nanohibrid ZCPL. Analisis inframerah transformasi Fourier (FTIR) menunjukkan kehadiran gabungan kumpulan berfungsi bagi ZLDH dan CPL kelihatan pada spektra ZCPL. Ini membuktikan CPL telah berjaya disisipkan di antara ruang hidroksida berlapis ganda bagi pembentukan bahan nanokomposit tersebut. Analisis CHNS menunjukkan bahan nanohibrid ZCPL mengandungi CPL dengan peratusan $30.63 \%(\mathrm{w} / \mathrm{w})$ yang ditentukan melalui pengiraan peratusan karbon di dalam sampel nanohibrid ZCPL. Luas permukaan BET telah meningkat daripada $1.7 \mathrm{~m}^{2} / \mathrm{g}$ kepada 10.9 m²/g masing-masing bagi ZLDH dan ZCPL. Struktur liang bahan nanohibrid yang terhasil juga telah berubah disebabkan penyisipan captopril telah mengembangkan jarak basal, begitu juga dengan pembentukan liang yang lebih besar berlaku hasil dari pembentukan bahan nanohibrid, ZCPL.
\end{abstract}




\section{Zaemah et al: SYNTHESIS AND CHARACTERISATION OF NANOHYBRID ANTI-HYPERTENSIVE DRUG, CAPTOPRIL INTERCALATED INTO ZINC-ALUMINIUM LAYERED DOUBLE HYDROXIDE}

Kata kunci: captopril, ubat anti-hipertensi, sisipan, hidroksida berlapis ganda, nanokomposit

\section{Introduction}

Hydrotalcites like anionic clay mineral or layered double hydroxide (LDH), comprise two dimensional inorganic nanolayers emerged as materials with numerous medical applications including gene delivery [1] and drug delivery [2]. The design of effective drug delivery has become significant in modern pharmaceutics, aiming at minimising secondary effects, increasing drug bioavailability and stability, and better localisation of the pharmaceutical action [3]. The basic structure of LDH was derived by the substitution of divalent cations in a brucite lattice by trivalent cations in such way that the layers acquire a positive charge, which is balanced by the intercalation of anions and water between the layers [4].

LDHs generally represented by the general formula $\left[\mathrm{M}^{\mathrm{II}}{ }_{1-\mathrm{x}} \mathrm{M}^{\mathrm{III}}{ }_{\mathrm{x}}(\mathrm{OH})_{2}\right]^{\mathrm{x}+}\left(\mathrm{A}^{\mathrm{n}-}\right)_{\mathrm{x} / \mathrm{n}} \cdot \mathrm{yH}_{2} \mathrm{O}$, where $\mathrm{M}^{\mathrm{II}}$ is the divalent metal cation $\left(\mathrm{Mg}^{2+}, \mathrm{Ca}^{2+}\right.$, and $\left.\mathrm{Zn}^{2+}\right), \mathrm{M}^{\mathrm{III}}$ is the trivalent metal cation $\left(\mathrm{Al}^{3+}, \mathrm{Cr}^{3+}, \mathrm{Fe}^{3+}\right.$, and $\left.\mathrm{Co}^{3+}\right)$, and $\mathrm{A}^{\mathrm{n}-}$ is the anion $\left(\mathrm{Cl}^{-}, \mathrm{CO}_{3}{ }^{2-}\right.$, and $\left.\mathrm{NO}_{3}{ }^{-}\right)$[5]. Nowadays, LDHs are well-known materials due to its interesting properties such as excellent anion exchange capacity [6], good adsorptive removal of dye and phenol [7,8], act as a controlled release formulation for nonsteroidal anti-inflammatory drugs (NSAIDs) [9] and has the potential to be used as drug delivery system [10]. It also has widespread application in the fields of catalysis [11], intumescent flame retardant [12], polymer [13], photocatalytic activity enhancement [14], ultrahigh energy density and stable supercapacitor [15], and good to be used as energy storage [16]. The layers of LDH possess positive charges which are counterbalanced by the anions present in the interlayer spacing and those anions are exchangeable with other suitable negatively charged species. The interlayer anion exchange capability of LDHs can be used to intercalate negatively charged functional biomolecules such as vitamins [17], DNA [18], and drugs within the LDH layer [19, 20]. Thus, $\mathrm{LDH}$ has the potential as a drug vehicle and could be used to regulate the release of drug from the drug intercalated LDH. Sustained drug release has the advantages as it could reduce the frequency of the drug intake and improve the patient's compliances [5].

In this study, captopril (CPL) drug which is a primary drug used for hypertension [14], was intercalated into the interlayer spaces of ZLDH by self-assembly method. The chemical structure of CPL is shown in Figure 1.

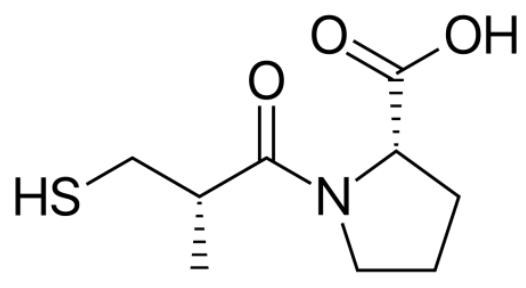

Figure 1. Chemical structure of CPL

The physicochemical properties of the zinc-aluminium-captopril (ZCPL) nanohybrid material will be discussed in this paper. The synthesised ZCPL nanohybrid material is expected to become a promising nanocarrier for CPL as a controlled release formulation for anti-hypertensive drugs.

\section{Materials and Methods}

All the chemicals used in the synthesis were obtained from various chemical suppliers and used without any further purification. All solution was prepared using deionised distilled water. Zinc nitrate hexahydrate $\left[\mathrm{Zn}\left(\mathrm{NO}_{3}\right)_{2} \cdot 6 \mathrm{H}_{2} \mathrm{O}\right]$, aluminium nitrate $\left(\mathrm{AlNO}_{3} \cdot 9 \mathrm{H}_{2} \mathrm{O}\right)$, sodium hydroxide $(\mathrm{NaOH}), \mathrm{CPL}\left(\mathrm{C}_{9} \mathrm{H}_{15} \mathrm{NO}_{3} \mathrm{~S}\right)$ were obtained from SigmaAldrich (USA), at $98 \%$ purity and used as received. 
The synthesis of ZCPL was done by self-assembly method. A mother liquor containing zinc cation $\left(\mathrm{Zn}^{2+}\right)$ and aluminium cation $\left(\mathrm{Al}^{3+}\right)$ with $\mathrm{Zn} / \mathrm{Al}$ initial ratio $\left(\mathrm{R}_{\mathrm{i}}=3\right)$ and $\mathrm{CPL}$ was prepared and the $\mathrm{pH}$ value that was adjusted to about 7.5. The concentration of CPL was $0.08 \mathrm{M}$ and the reaction was carried out by stirring the solution under nitrogen atmosphere. The solution was aged for 18 hours in an oil bath shaker at $70{ }^{\circ} \mathrm{C}$. The resulting precipitate was centrifuged, thoroughly washed, and dried in an oven at $70{ }^{\circ} \mathrm{C}$ for 3 days and kept in a sample bottle for further use and characterisations. A similar method was adopted for the preparation of ZLDH with nitrate anion $\left(\mathrm{NO}_{3}{ }^{-}\right)$as the intergallery anion by omitting the addition of CPL solution in the mother liquor.

Powder X-ray diffraction (PXRD) patterns of the samples were obtained by a Shimadzu diffractometer XRD-6000, using the filtered $\mathrm{CuK}_{\alpha}$ radiation. FTIR spectra were recorded by a Perkin-Elmer 1750 spectrophotometer. $\mathrm{KBr}$ pellet containing $1 \%$ sample was used to obtain the FTIR spectra. The surface morphology of the samples was observed by a scanning electron microscope (SEM), using JOEL JSM-6400. CHNS-O analyser, model EA 1108 of Finons Instruments was used for CHNS-O analysis. The surface characterisation of the materials was carried out by nitrogen gas adsorption desorption at $77 \mathrm{~K}$ using micromeritics ASAP 2000. Samples were degassed in an evacuated-heated chamber at $120^{\circ} \mathrm{C}$ overnight.

\section{Powder X-ray diffraction}

\section{Results and Discussion}

Figure 2(a) shows PXRD patterns of ZLDH, CPL, and ZCPL. The PXRD patterns show a sharp, intense, and symmetry peak indicating a well-ordered nanolayered structure was formed in the resulting materials. As shown in the figure, CPL anion was successfully intercalated inside the interlayer of ZLDH with the increased of the basal spacing from $8.90 \AA$ in ZLDH to $9.69 \AA$ in the nanocomposite, ZCPL. The expansion of the basal is due to the inclusion of CPL anion into the ZLDH lamella, which is bigger than $\mathrm{NO}_{3}{ }^{-}$.
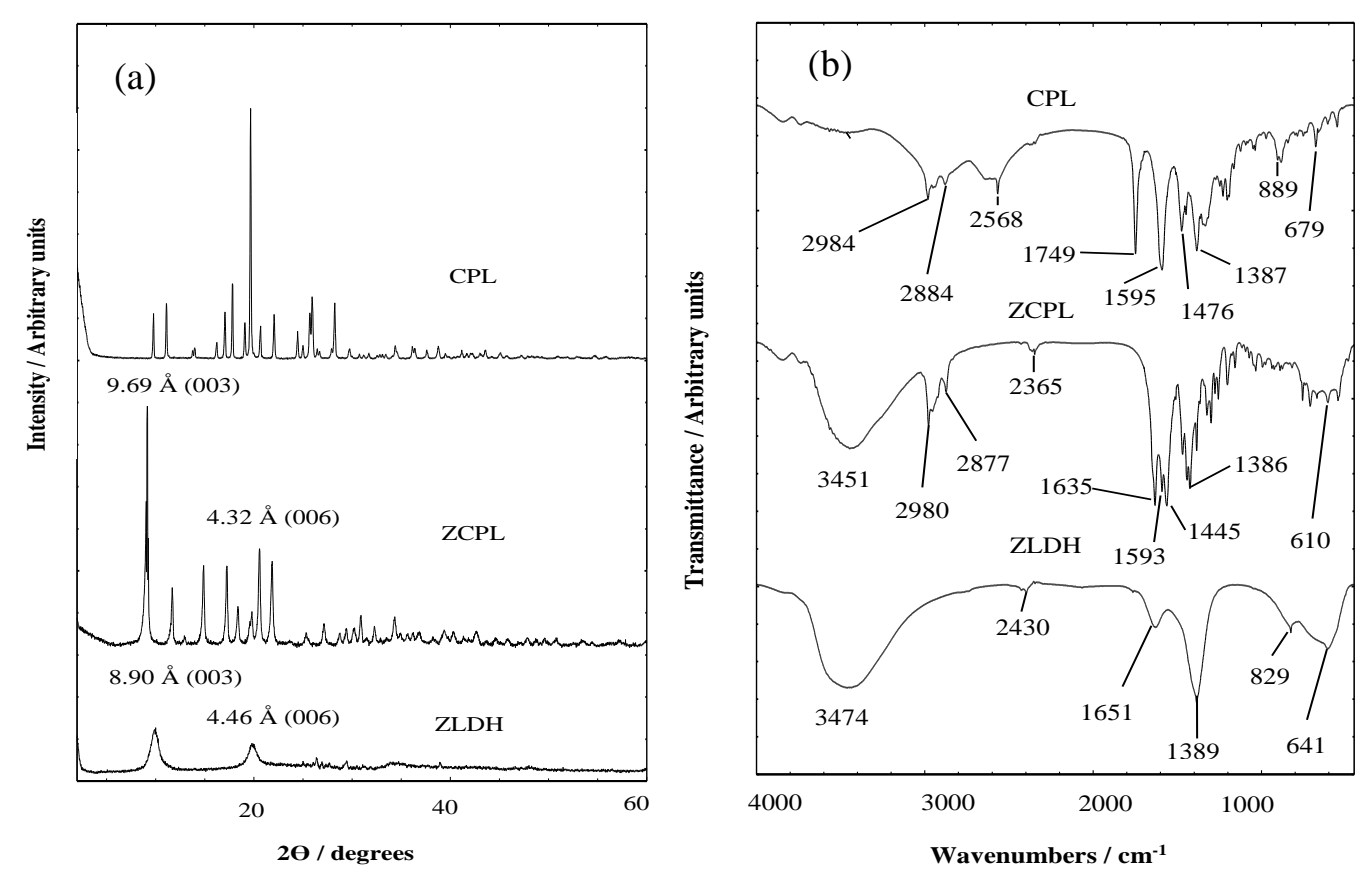

Figure 2. The PXRD patterns of (a) ZLDH, ZCPL, and CPL and (b) FTIR spectra for ZLDH, ZCPL, and CPL

\section{Fourier transform infrared spectroscopy}

Figure 2(b) shows the FTIR spectra for CPL, ZLDH, and ZCPL nanocomposites. The FTIR spectrum for ZLDH shows a broad absorption band at around $3474 \mathrm{~cm}^{-1}$ which is due to the presence of $\mathrm{OH}$ stretching modes of the 


\section{Zaemah et al: SYNTHESIS AND CHARACTERISATION OF NANOHYBRID ANTI-HYPERTENSIVE DRUG, CAPTOPRIL INTERCALATED INTO ZINC-ALUMINIUM LAYERED DOUBLE HYDROXIDE}

hydroxyl group in LDH. The band at $1642 \mathrm{~cm}^{-1}$ is due to the bending vibration of the interlayer water molecule. A sharp and intense peak located at approximately $1389 \mathrm{~cm}^{-1}$ is attributed to the stretching vibration of $\mathrm{NO}_{3}^{-}$[22]. Another band at 829 and $641 \mathrm{~cm}^{-1}$ are due to the translation vibrations at $\mathrm{Zn}-\mathrm{OH}$ and deformation vibration of $\mathrm{OH}-$ $\mathrm{Zn}-\mathrm{Al}-\mathrm{OH}$, respectively [23].

The FTIR spectrum for CPL shows the characteristic frequencies at $889 \mathrm{~cm}^{-1}$ due to the $-\mathrm{CN}$ bending vibration, $1595 \mathrm{~cm}^{-1}$ due to the nitrogen ring, and $1749 \mathrm{~cm}^{-1}$ indicating the carboxylate ion $\left(\mathrm{COO}^{-}\right)$from $\mathrm{COOH}$ group. Characteristic peak at $2568 \mathrm{~cm}^{-1}$ indicates the presence of -SH group of CPL [24].

As expected, the FTIR spectrum of ZCPL resembles a mixture of both the spectra of CPL and ZLDH, indicating that both functional groups of CPL and ZLDH simultaneously present in ZCPL and confirms the intercalation of CPL in the interlamellar of ZCPL. The presence of the absorption band at $1386 \mathrm{~cm}^{-1}$ indicates the presence of CPL anion in ZCPL replacing $\mathrm{NO}_{3}^{-}$in ZLDH. This shows that CPL has higher affinity than $\mathrm{NO}_{3}^{-}$towards the inorganic interlamellar, thus occupies the interlamellar region between the inorganic layers and prevents further cointercalation of $\mathrm{NO}_{3}{ }^{-}$. The most important feature in the FTIR spectra is the presence of new band at around 2980 and $610 \mathrm{~cm}^{-1}$ which indicates the presence of $\mathrm{S}-\mathrm{H}$ and $\mathrm{C}-\mathrm{S}$ stretching, respectively. This new band at $1593 \mathrm{~cm}^{-1}$ is due to the nitrogen ring of CPL, which confirms the presence of CPL in the interlayer spaces of the ZLDH.

\section{Spatial orientation of captopril drug in Zn-Al-CPL nanocomposite}

Based on the three dimensional molecular structure of CPL, the calculation obtained using Chem 3D Ultra 8.0 software is ilustrated in Figure 3(a). The length, height, and thickness of the CPL molecular structure were estimated to be 5.9, 5.0, and $3.2 \AA$, respectively. The ZLDH is composed of inorganic layers with octahedral coordinated $\mathrm{Zn}^{2+}$. The CPL was suggested to be oriented in the interlayer gallery of ZLDH in a monolayer arrangement and was held in the orientation as shown in Figure 3(b) by the electrostatic attraction from the excess positive charge of ZLDH [21]. In the proposed spatial arrangement of CPL within the interlayer of ZLDH, the molecular structure of CPL is expected to be slightly slanted.

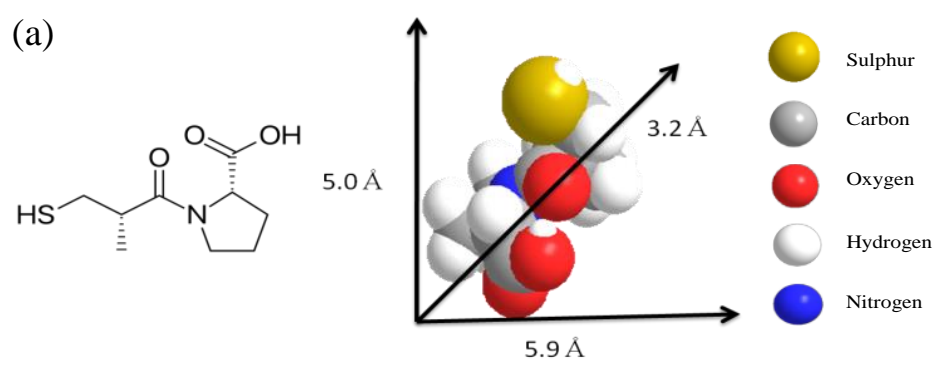

(b)

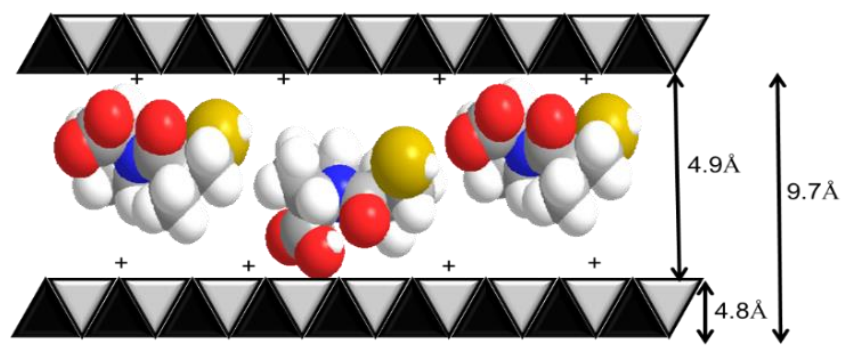

Figure 3. (a) Molecular structure of CPL and three-dimensional molecular size of CPL and (b) proposed spatial orientation of CPL in the interlayer of ZLDH

\section{CHNS analysis}

The CHNS analysis shows that ZCPL contained $30.63 \%$ of carbon, and $8.70 \%$ of sulfur which indicate that CPL was successfully intercalated into the lamellae of ZCPL. The percentage of nitrogen of $3.10 \%$ is due to the presence 
of $\mathrm{NO}_{3}{ }^{-}$in $\mathrm{ZLDH}$. And since the CPL also contains nitrogen atom, the $4.48 \%$ of nitrogen detected in CHNS analysis is due to the nitrogen atom of CPL.

\section{Isotherm, surface area and pore size distribution}

Figure 4(a) shows the adsorption-desorption isotherm for ZLDH and ZCPL nanocomposite material. As shown in the figure, the adsorption-desorption for ZCPL was Type IV, indicating a mesoporous-type material (20-500 $⿱$ ) [25], with adsorption of a slow uptake of the adsorbent at a relative pressure of $0.05-0.8$. Further increase of a relative pressure to $>0.8$ resulted in a rapid adsorption of the adsorbent, reaching an optimum at more than $45 \mathrm{~cm}^{3} / \mathrm{g}$ at STP. A general shape of the isotherm for ZCPL did not differ very much from ZLDH; the Type IV isotherm remains. However, as shown in Figure 4(a), the adsorbate uptake was slow in the relative pressure range 0.05-0.9, after that rapid adsorption was observed. An optimum uptake of $5 \mathrm{~cm}^{3} / \mathrm{g}$ at STP, indicates the slow uptake of the nitrogen gas. Desorption branch of the hysteresis loop for ZCPL was narrower compared to that of ZLDH, indicating different pore texture of the resulting material. This can be related to the different pore structure when $\mathrm{NO}_{3}{ }^{-}$was replaced by CPL during the formation of ZCPL with the formation of interstitial pores between the crystallite, different particle size, and morphology.
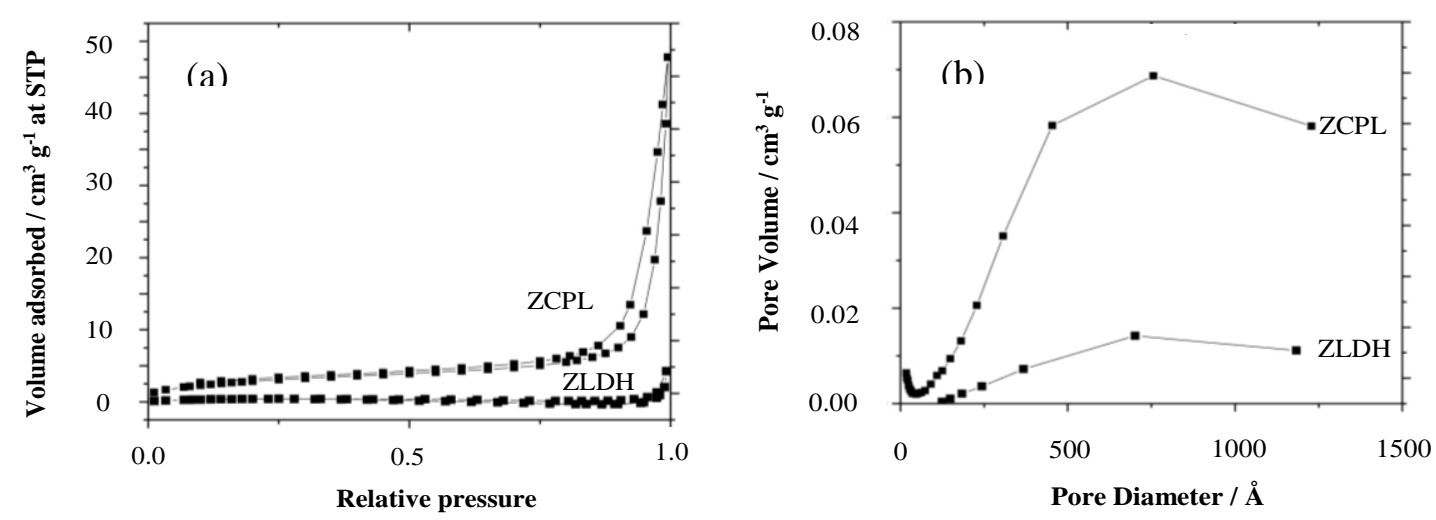

Figure 4. (a) Adsorption-desorption isotherms for nitrogen gas at $77 \mathrm{~K}$ for ZLDH and ZCPL and (b) BJH pore size distribution for ZLDH and ZCPL

The surface properties of ZLDH and ZCPL are summarised in Table 1. The intercalation of CPL has increased the BET specific surface area from $1.7 \mathrm{~m}^{2} / \mathrm{g}$ in ZLDH to $10.9 \mathrm{~m}^{2} / \mathrm{g}$ in ZCPL, which is due to the inclusion of bigger guest anion than the counter anion, $\mathrm{NO}_{3}{ }^{-}$. The intercalation of bigger anion of CPL resulting in the expansion of basal spacing of the resulting ZCPL nanocomposite and creates more pores in the crystallites, therefore the surface area increased significantly. Table 1 also shows that the BET average pore diameter for ZCPL was lower than that of ZLDH with 203 and $217 \AA$, respectively. On the other hand, the BJH desorption pore volume of ZCPL was higher than that of ZLDH.

Table 1. Elemental and surface properties of ZLDH and its intercalated compound, ZCPL

\begin{tabular}{|c|c|c|c|c|c|c|c|c|}
\hline Material & $\begin{array}{c}\text { Basal } \\
\text { spacing } \\
(\AA)\end{array}$ & $\begin{array}{l}\% \\
\mathrm{C}\end{array}$ & $\begin{array}{l}\% \\
\mathbf{N}\end{array}$ & $\begin{array}{l}\% \\
\mathbf{S}\end{array}$ & $\begin{array}{c}\text { BET } \\
\text { Surface } \\
\text { Area } \\
\left(\mathbf{m}^{2} \mathbf{g}^{-1}\right)\end{array}$ & $\begin{array}{c}\text { BJH } \\
\text { Desorption } \\
\text { Pore Volume } \\
\left(\mathbf{c m}^{\mathbf{3}} \mathbf{g}^{-1}\right)\end{array}$ & $\begin{array}{c}\text { BET } \\
\text { Average } \\
\text { Pore } \\
\text { Diameter } \\
\text { (̊) }\end{array}$ & $\begin{array}{c}\text { BJH } \\
\text { Average } \\
\text { Pore } \\
\text { Diameter } \\
(\AA)\end{array}$ \\
\hline ZLDH & 8.90 & 0.0 & 3.10 & 0.0 & 1.7 & 0.010 & 217 & 161 \\
\hline ZCPL & 9.69 & 30.63 & 4.48 & 8.70 & 10.9 & 0.282 & 203 & 199 \\
\hline
\end{tabular}




\section{Zaemah et al: SYNTHESIS AND CHARACTERISATION OF NANOHYBRID ANTI-HYPERTENSIVE DRUG, CAPTOPRIL INTERCALATED INTO ZINC-ALUMINIUM LAYERED DOUBLE HYDROXIDE}

The BJH pore size distribution for ZLDH and ZCPL are presented in Figure 4(b). Both materials show mesoporous type of material, with the adsorption isotherm Type IV. The BJH pore size distribution for ZLDH shows a broad peak at around $701 \AA$ while for ZCPL an intense peak centered at around $756 \AA$ indicating modification of pore texture in agreement with the formation of a new intercalated compound, ZCPL with basal spacing of $9.69 \AA$.

\section{Surface morphology}

Figures 5(a) and 5(b) show the field effect scanning electron microscopy (FESEM) morphology of ZLDH and ZCPL. ZLDH shows the typical morphology of LDH which shows agglomerates of compact and flake-like structure. The morphology of ZCPL shows a porous rod-like structure as the result of the intercalation of CPL into the layered structure of ZLDH. As shown in the figures, there was no significant difference in the morphology of the two samples. They were also very similar to the morphology of other intercalated compound of nanocomposites which has been reported earlier [22,26].
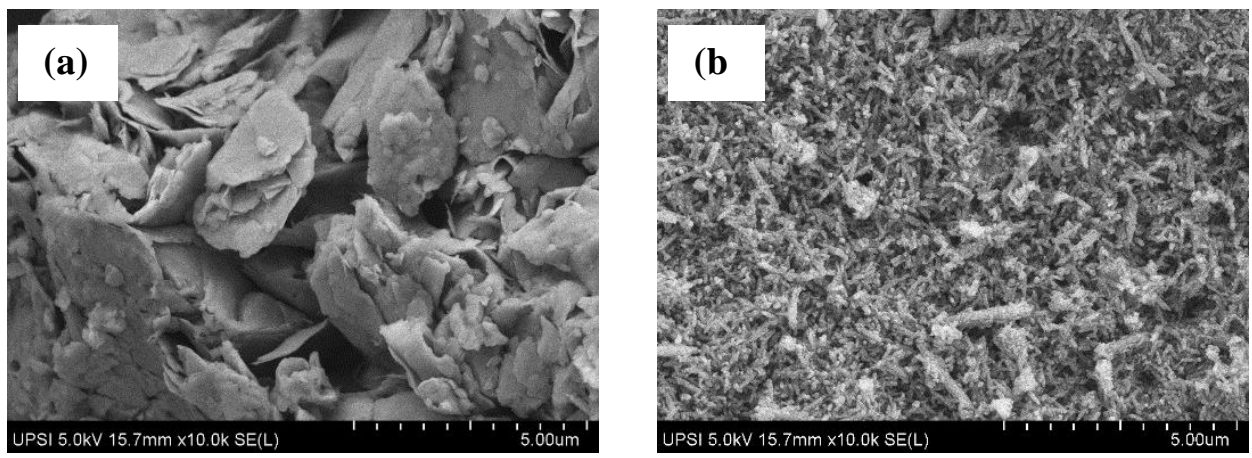

Figure 5. Scanning electron micrograph for ZLDH (a) and ZCPL (b) at 10, 000x magnification

\section{Conclusion}

The layered organic-inorganic nanohybrid was prepared using anti-hypertensive drug, CPL as an anionic guest and intercalated into the interspaces host of ZLDH by self-assembly method. The initial Zn: Al molar ratio of the mother liquor was 3:1 with $\mathrm{pH} 7.5$ after the addition of $\mathrm{NaOH}$. The PXRD pattern shows the basal spacing increased from $8.90 \AA$ in ZLDH to $9.69 \AA$ in ZCPL to accommodate the CPL anion to form hybrid nanocomposite of ZCPL. FTIR spectra of ZCPL resembles the functional groups of ZLDH and CPL and confirmed the CPL drug was successfully inserted into the interlayer structure of ZLDH. The BET surface area of the material increased from $1.7 \mathrm{~m}^{2} / \mathrm{g}$ in ZLDH to $10.9 \mathrm{~m}^{2} / \mathrm{g}$ in ZCPL if $0.08 \mathrm{M}$ of CPL was used in the formation of nanohybrid. The pore texture of the resulting materials also changed as a result of the intercalation and the expansion of the basal spacing together with pore formation between the crystallite during the formation of the resulting intercalated ZCPL nanocomposite. The synthesised ZCPL nanohybrid material is expected to become a promising nano carrier for CPL as controlled release formulation for anti-hypertensive drugs.

\section{Acknowledgement}

The funds for the research were provided by Universiti Tenaga Nasional (UNITEN) and the Ministry of Higher Education of Malaysia (MOHE) under FRGS grant Vot No. 20160107FRGS.

\section{References}

1. Ladewig, K., Marcus, M., Zhi, P. X., Gray, P. P. and Gao, Q. (2010). Controlled preparation of layered double hydroxide nanoparticle and their application as gene delivery vehicles. Applied Clay Science, 48(12): $280-$ 289.

2. Suman, S., Sayantan, R., Rituparna, A., Tapan, K. C. and Jui, C. (2017). Magnesium, zinc and calcium aluminium layered double hydroxide drug nanohybrids: A comprehensive study. Applied Clay Science, 135: $493-509$. 
3. Kuthati, Y., Kankala, R. K. and Lee, C. H. (2015). Layered double hydroxide nanoparticles or biomedical applications: Current status and recent prospects. Applied Clay Science, 112-113:100 - 116.

4. Duan, X. and Evans, D. G. (2006). Layered double hydroxides, structure and bonding. Springer, Berlin, pp. 1 234.

5. Sudipte, S., Ravi, T., Shiv, P., Shivali, D., Durga, P. M., Parimal, D., Shripathi, T., Mohan, K., Dipak, R. and Pralay, M. (2016). Layered double hydroxide as effective carrier for anticancer drug and tailoring of release rate through interlayer anions. Journal of Controlled Release, 224: 186 - 198.

6. Salak, A. N., Tedim, J., Alena, I. Kuznetsova, Mikhail, L. Maria, G. S. F. (2010). Anion exchange in Zn-Al layered double hydroxide: In-situ X-ray diffraction study. Chemical Physics Letters, 495: 73 - 76.

7. Chakrabarty, A. and Acharya, H. (2018). Facile synthesis of MgAl-layered double hydroxide supported metal organic framework nanocomposite for adsorptive removal of methyl orange dye. Colloid and Interface Science Communications, 24: 35 - 39.

8. Lupa, L., Cocheci, L., Pode, R. and Hulka, L. (2018). Phenol adsorption using aliquat 336 functionalized Zn-Al layered double hydroxide. Separation and Purification Technology, 196: 82 - 95.

9. Rives, V., Arco, M. D. and Martin, C. (2013). Layered double hydroxides as drug carriers and for controlled release of non-steroidal anti-inflammatory drugs (NSAIDs): A review. Journal of Controlled Release, 169: 28 39

10. Zhang, K., Xu, Z. P., Lu, J., Tang, Z. Y., Zhao, H. J., Good, D. A. and Wei, M. Q. (2014). Potential for layered double hydroxides-based innovative drug delivery systems. International Journal of Molecular Sciences, 15: $7409-7428$.

11. Sipos, P. and Palinko, I. (2018). As-prepared and intercalated layered double hydroxides of the hydrocalumite type as efficient catalysts in various reactions. Catalysis Today, 306: $32-41$.

12. Zhang, S., Yan, Y., Wang, W., Gu, X., Li, H., Li, J. and Sun, J. (2018). Intercalation of phosphotungstic acid into layered double hydroxide by reconstruction method and its application in intumescent flame-retardant poly(lactic acid) composites. Polymer Degradation and Stability, 147:142-150.

13. Sorrentino, A., Gorassi, M., Tortora, M., Vittoria, V., Constantino, U., Marmottini, F., Padella, F. (2005). Incorporation of $\mathrm{Mg}$-Al hydrotalcite into a biodegradable poly( $\mathcal{E}$-caprolactone) by high energy ball miling. Polymer 45: 1601 - 1608

14. Dutta, K., Das, S. and Pramanik, A. (2012). Concomitant synthesis of highly crystalline Zn-Al layered double hydroxide and $\mathrm{ZnO}$ : Phase interconversion and enhanced photocatalytic activity. Journal of Colloid and Interface Science, 366: 28 - 36.

15. Xiao, Y., Su, D., Wang, X., Wu, S., Zhou, L., Sun, Z., Wang, Z., Fang, S. and Li, F. (2017). Ultrahigh energy density and stable supercapacitor with 2D NiCoAl Layered double hydroxide. Electrochimica Acta, 253: 324 332 .

16. Shao, M., Zhang, R., Li, Z., Wei, M. Evans, D. E. and Duan, X. (2015). Layered double hydroxide toward electrochemical energy storage and conversion: Design, synthesis and applications. Chemical Communication, 51: $15880-15893$.

17. Gasser, M. S. (2009). Inorganic layered double hydroxides as ascorbic acid (vitamin C) delivery system intercalation and their controlled release properties. Colloids Surface B, 73: $103-109$

18. Li, Y., Bao, W., Wu, H., Wang, J., Zhang, Y., Wan, Y., Cao, D. and Wang, Q. (2017). Delaminated layered double hydroxide delivers DNA molecules as sandwich nanostructure into cells via a non-endocytic pathway. Science Bulletin, 62(10): 686 - 692.

19. Rojas, R., Linck, Y. G., Cuffini, S., Monti, G. and Giacomelli, C. E. (2015). Structural and physicochemical aspects of drugs release from layered double hydroxides and layered hydroxide salts. Applied Clay Science, 109-110: $119-126$.

20. Rives, V., Arco, M. and Martin, C. (2014). Intercalation of drugs in layered double hydroxides and their controlled release: A review. Applied Clay Science, 88-89: 239 - 269.

21. Mohsin, S. M. N., Hussein, M. Z., Sarijo, S. H., Fakurazi, S., Arulselvan, P. and Yun Hin, T. Y. (2013). Synthesis of (cinnnamate-zinc layered hydroxide) intercalation compound for sunscreen application. Chemistry Central Journal, 26(7): 1 - 12.

22. Legrouri A., Badreddine, A., Barroug, A., Roy, J. P., Besse, P. (1999). Influence of pH on the synthesis of ZnAl-nitrate layered double hydroxide and the exchange of nitrate by phosphate ions. Journal of Material Science Letters, 18: 1077 - 1079. 
Zaemah et al: SYNTHESIS AND CHARACTERISATION OF NANOHYBRID ANTI-HYPERTENSIVE DRUG, CAPTOPRIL INTERCALATED INTO ZINC-ALUMINIUM LAYERED DOUBLE HYDROXIDE

23. Hussein, M., Zainal, Z. and Hwa, T. K. (2000). Synthesis and properties of layered organic-inorganic hybrid material: $\mathrm{Zn}-\mathrm{Al}$ layered double hydroxide-dioctyl sulfosuccinate nanocomposite. Journal of Nanoparticle Research, 2: 293 - 298.

24. Srivastava, A., Khare, B., Argal, R. and Patel, S. (2003). Microdetermination of anti-hypertensive drug captopril using 2,6-dichlorophenol indophenol. Indian Journal of Chemistry, 42: 3036 - 3040.

25. Jubri, Z., Mohd Yusuf, N. Z. A., Sarijo, S. H., Marsom, E. S. and Hussein, M. Z. (2017). Synthesis, characterization and controlled release properties of zinc-aluminium-beta-naphtoxyacetate nanocomposite. Journal of Porous Materials, 24(3): 573 - 582.

26. Xu, Z. P. and Braterman, P. S. (2010). Synthesis, structure and morphology of organic layered double hydroxide (LDH) hybrids: Comparison between aliphatic anions and their oxygenated analogs. Applied Clay Science, 48: $235-242$. 